Research Report No. 58/2013

\title{
Can Worker Voice Strike Back? Law and the Decline and Uncertain Future of Strikes
}

Eric Tucker

Osgoode Hall Law School of York University, etucker@yorku.ca

Follow this and additional works at: http:// digitalcommons.osgoode.yorku.ca/clpe

\section{Recommended Citation}

Tucker, Eric, "Can Worker Voice Strike Back? Law and the Decline and Uncertain Future of Strikes" (2013). Comparative Research in Law of Political Economy. Research Paper No. 58/2013.

http://digitalcommons.osgoode.yorku.ca/clpe/300 


\section{OSGOODE}

\section{OSGOODE HALL LAW SCHOOL}

Comparative Research in Law \& Political Economy

RESEARCH PAPER SERIES

Research Paper No. 58/2013

Can Worker Voice Strike Back? Law and the Decline and Uncertain Future of Strikes

Eric Tucker

\section{Editors:}

Peer Zumbansen (Osgoode Hall Law School, Toronto, Director Comparative Research in Law and Political Economy)

John W. Cioffi (University of California at Riverside) 
Can Worker Voice Strike Back? Law and the Decline and Uncertain Future of Strikes

Eric Tucker ${ }^{1}$

Professor, Osgoode Hall Law School, York University

A later version will be published in, Alan Bogg and Tonia Novtiz, eds., Voices at Work (Oxford University Press, 2014)

${ }^{1}$ I would like to thank the editors of this volume, Tonia Novitz and Alan Bogg for their helpful comments on an earlier draft, as well as Shae McCrystal for her comments on the Australian law. I also want to thank Osgoode Hall Law School students Jeffrey Rochwerg and Njeri Damali Campbell for research and editorial assistance. 
The relation between worker voice and strikes is a long one. For most of the past 200 years, the withdrawal of labour has been the principal, perhaps, quintessential expression of collective worker voice. ${ }^{2}$ This was true whether workers were organized on a craft or an industrial basis, although the pattern of organization certainly affected the form that strikes took. ${ }^{3}$ The frequency and length of strikes varied considerably over time and place, but the strike remained the weapon of choice if a weapon was needed to achieve common workplace objectives. ${ }^{4}$ However, the venerable age of this practice does not guarantee its continuation. Like a roof with a slow leak, one day a storm may come and suddenly the roof collapses, its supporting structure irreparably weakened, the victim of rot gone undetected for too long. Have we reached this point with strikes? In most advanced capitalist countries, we have witnessed the collapse of the strike over the last few decades. Have the structural and legal conditions that supported strikes eroded so thoroughly that exhortations to revive the strike are as futile as planning to raise a roof without first making sure there is a structure in place that can support it?

The purpose of this chapter is not to provide a definitive answer the question of the future of strikes as the quintessential expression of collective worker voice, but rather to contribute toward a discussion of it by providing an overview of the literature in three strike-related areas: recent data on the incidence of strikes; an examination of the role that law plays in influencing strike incidence; and speculation on the future of collective worker resistance.

However, before launching into these other topics, it will be helpful by way of introduction to spend a little time identifying the ways in which worker voice has been connected to strike activity. ${ }^{5}$ The most frequent and popular view of strikes is as an economic weapon that enables workers to enjoy some countervailing power and make collective bargaining meaningful. The absence of a right to strike, or more generally, the absence of an effective threat to collectively withdraw labour and put economic pressure on employers, is said to transform

collective bargaining into "collective begging." ${ }^{6}$ In Canada, the Woods Task Force, which in 1967 articulated the underlying principles of the post-World War II industrial relations

\footnotetext{
${ }^{2}$ Peter Rachleff, 'Is the Strike Dead? An Historical Look at the Future' (2003) 12:2 New Labor Forum 87. For a discussion of earlier forms of collective labour protest, including rioting and machine breaking, see P.K. Edwards, Conflict at Work (Basil Blackwell, Oxford 1986) ch. 4. Edwards makes the important analytic point that forms of protest are linked to changing relations of production, so that strikes should not be seen simply as a "drift to modernity" (112). This insight has important implications for discussions of the future of collective action, to which we will return in the last section of the paper.

${ }^{3}$ Joe Burns, Reviving the Strike (Ig Publishing, New York 2012) 14-17.

${ }^{4}$ The incidence of strikes is not a good measure of the strength of worker voice. More important is the plausibility of the threat of the strike. Thus in a world in which workers' organization is strong, employers may find it it is in their self-interest to cooperate with labour and make concessions, rather than to fight. See Erik Olin Wright, 'Working-Class Power, Capitalist-Class Interests, and Class Compromise' (2000) 105 AJS 957. It is implausible that the current decline in strikes reflects growing working-class strength. Union densities are declining as is labour's share of national income. For Canadian data, see Gary Sran and others, Unions Matter (Canadian Foundation for Labour Rights, Ottawa 2013). For U.S. data, see Fred Magdoff and John Bellamy Foster, 'Class War and Labor’s Declining Share’ (2013) 64 MR, 1.

${ }^{5}$ For an excellent overview, see Tonia Novitz, International and European Protection of the Right to Strike (OUP, Oxford 2003) 39-73.

${ }^{6}$ The origin of the term is unknown. Its earliest use, identified through a search of Google Books Ngram Reader, was in 1921. It was popularized by an article in Time magazine, 'U.S. At War: No Collective Begging' Time (25 September 1944) quoting a
} 
system, stated that strikes are "an indispensable part of the Canadian industrial relations system"7 and that "[t]he acceptance of collective bargaining carries with it a concomitant recognition of the right to invoke the economic sanction of the strike and the lockout." 8

The connection between voice and strikes, however, is not just limited to the achievement of better terms and conditions of employment. Strikes are often viewed as a means for workers to exercise democratic voice. Thus, the Woods Task Force asserted that strikes had become "a part of the whole democratic system."9 What they meant was that trade unionism contributed to the development of industrial democracy, the ability of workers to participate in workplace governance, and not just the determination of terms and conditions of employment. Of course, the forms that industrial democracy could take varied considerably, but in the North American context, where almost any form of codetermination or social dialogue was beyond the pale, collective bargaining and its associated institutions were the principal vehicle for worker participation in workplace governance. ${ }^{10}$

State policy, however, never fully embraced this goal, and in particular was deeply opposed to permitting strikes as a vehicle for the expression of worker voice over day to day workplace governance issues. ${ }^{11}$ In the Wagner Act model, grievance arbitration was to be the mechanism for resolving these disputes and strikes during the life of the collective agreement were prohibited, either by legislation (Canada) or by the express or implied terms of the collective agreement (US). More recently Australia and New Zealand have also prohibited midterm strikes However, prohibitions on strikes do not always stop workers from engaging in unauthorized strikes to protest against managerial decision-making and, perhaps, official union inaction. Indeed, there have been times when so-called wildcat strikes were quite frequent and viewed with alarm by those who thought of institutionalized collective bargaining primarily as a means for maintaining industrial order ${ }^{12}$. In the UK, where strikes during the life of a collective

disgruntled union member opposed to the wartime no strike pledge who declared,“Hell, we haven’t even got collective begging, let alone collective bargaining.” Barrett, Grant, 'Collective Begging' (Online Dictionary)

$<$ http://www.waywordradio.org/collective_begging_1/> accessed 16 September 2013. Its use declined in the 1950s, but attained even greater popularity in the 1960s and 70s as public sector unions fought to obtain formal collective bargaining rights and the right to strike. See Google Ngram Viewer, 'Collective Begging'

<http://books.google.com/ngrams/graph?content=collective+begging\&year_start=1800\&year_end=2000\&corpus=15\&smoothing =3\&share > accessed 16 September 2013. (I am indebted to Bob Sink for providing me with this link.) The term is now generally used to describe collective bargaining schemes in which workers lack an effect right to strike. For example, see Daniel Pollitt, 'McKay Radio Turn it Off, Tune it Out' (1991) 25 U SF L Rev 295, 297 (“In sum, without the right to strike, collective bargaining denigrates into collective begging.”). NLRB v Mackay Radio \& Telegraph Co. 304 US 333 (1938) allowed employers to hire permanent replacement workers during a strike.

${ }^{7}$ Report of the Task Force on Labour Relations, 'Canadian Industrial Relations’ PCO (1968) [39], [408].

${ }^{8}$ Ibid [605].

${ }^{9}$ Ibid [608].

${ }^{10}$ Nelson Lichtenstein and Howell J. Harris (eds), Industrial Democracy in America (Cambridge University Press, Cambridge 1993).

${ }^{11}$ Josiah B. Lambert, If the Workers took a Notion: The Right to Strike and American Political Development (Cornell University Press, New York 2005).

${ }^{12}$ For Canada, see L Briskin, 'Public Sector Militancy, Feminization, and Employer Aggression’ in Sjaak van der Velden et al. (eds), Strikes Around the World (Aksant, Amsterdam 2007) 86, 95-96. (Overall, between 1960 and 2004, 18\% of strikes were wildcats. At their peak in 1974, 40\% of all strikes were wildcats). Official statistics on wildcat strikes are not kept in the U.S. For a discussion, see R Fantasia, Cultures of Solidarity (University of California Press, Berkeley 1988) 59-65. For the UK, see D 
agreement were not illegal, workers faced fewer impediments to engaging in direct action to express their dissatisfaction with management actions. Notably, most strikes before 1980 were not officially supported by trade unions. The situation under current UK law is quite different. Mid-term strikes are still not prohibited, but like other strikes they must be 'official' if participating workers are to be immune from the threat of dismissal for the protected period. Where strike action is 'unofficial' the employment tribunal has no jurisdiction to deal with an unfair dismissal claim by the dismissed striker. The result is that workers participating in unofficial strikes can be selectively dismissed. It is also important to note that there are significant hurdles to making strikes official. ${ }^{13}$

A related but far more controversial question is the link between strikes and political democracy and, in particular, the role of strikes aimed at influencing government policies. Leaving aside the question of strikes aimed at overthrowing governments, the major objection to political strikes that seek to influence government policies that affect the interests of workers is that economic pressure may disrupt the 'normal' legislative and political process. The difficulty with that argument is that is fails to take into account the ways that capital routinely influences government policy by the threat to withdraw investment if business friendly policies are not pursued. ${ }^{14}$ The fact that many individual capitals can be gathered within a corporation, which is a distinct legal person, may mask its collective character, but it does not change it. ${ }^{15}$ Moreover, the boundaries between a political strike and a collective bargaining strike become blurred in the context of the public sector where 'ordinary' government legislation and executive action, let alone 'special' legislation targeting particular negotiations, so pervasively influences bargaining outcomes. ${ }^{16}$ The Woods Task Force anticipated this situation and seemed resigned to the inevitability of political strikes. ${ }^{17}$ These arguments, however, have had little legal traction. In Canada, political strikes are almost always unlawful and, indeed, at one time were liable to be criminally prosecuted as seditious conspiracies. ${ }^{18}$ In New Zealand and Australia political strikes are unlawful and participants are subject to various penalties. ${ }^{19}$ In the United Kingdom political strikers lose their statutory immunity from unfair dismissal and unions may become liable for economic torts, although there is a very small chance this may change as a result of the UK's

Lyddon, 'From Strike Wave to Strike Drought' in Strikes (see above in this note) 338. In the UK, there is some evidence that younger workers engage in collective action to resolve workplace complaints, but this does not seem to include strikes. See, Anna Pollert, 'Spheres of collectivism: Group Action and Perspectives on Trade Unions Among The Low-Paid Unorganized With Problems at Work’ (2010) 34 Capital \& Class 115.

${ }^{13}$ Pascale Lorber and Tonia Novitz, Industrial Relations Law in the UK (Intersentia, Cambridge 2012) 113.

${ }^{14}$ For an insightful discussion, see Novitz (n 5) 54-64.

${ }^{15}$ Claus Offe and Helmut Wiesenthal, 'Two Logics of Collective Action: Theoretical Notes on Social Class and Organizational Form' (1980) 1 Political Power and Social Theory 67.

${ }^{16}$ Leo Panitch and Donald Swartz, From Consent to Coercion: The Assault on Trade Union Freedoms (Garamond Press, Toronto 2003).

17 "The political strike cannot be done away with by legislation; and it is a phenomenon that might become more common as governments becomes increasingly involved in economic and social planning as well as in industrial relations.” Task Force on Labour Relations (n 7) [610].

${ }^{18}$ Domglas Ltd. [1976] OLRB Rep, October 569 (Ontario Labour Relations Board Reporter); Reinhold Kramer and Tom Mitchell, When the State Trembled (University of Toronto Press, Toronto 2010).

${ }^{19}$ B Brooks, 'Australia’ in R Blanpain (ed), International Encyclopedia for Labour Law and Industrial Relations (University of Leuven, Belgium 2009) 233; G Anderson, 'New Zealand’ in Blanplain (see above in this note) 206-07. 
international obligations under the ILO and the European Convention on Human Rights. The situation is more ambiguous in the United States. ${ }^{20}$

Finally, strikes have been viewed not merely as a manifestation of collective worker voice, but as an activity that produces higher levels of class consciousness, organization and, ultimately, power. This Marxist notion views consciousness as the product of human activity, so that although workers' interests may be structurally in conflict with those of capital, it is through the process of confrontation that workers are transformed and become a class for itself. ${ }^{21}$ The dialectical relationship between social activity and consciousness, of course, is not uniquely linked to participation in strikes, but in a world in which the repertoire of confrontation practices was built around the strike, their disappearance is deeply concerning and raises the pressing questions of whether the strike can be revived and if not whether new repertoires are in the making. We will return to these questions later in this chapter, but next we turn to evidence on the extent of strike activity.

\section{The Withering Away of the Strike?}

Anyone familiar with the literature on strike activity should be reluctant to use the above subtitle lest they suffer the same fate as functionalist industrial relations scholars in the 1950s who viewed the decline in strikes they witnessed evidence for their theory that industrial conflict would decline in advanced industrialized societies which had become more adept at containing, redirecting and controlling the sources and manifestations of unrest. ${ }^{22}$ That prediction, of course, turned out to be spectacularly wrong soon after it was made, as a massive strike wave hit industrialized countries in the late 1960s and early 1970s. The discussion of recent strike trends here, therefore, disavows any broader claim about its significance for the future. Rather, Figure 1simply presents, for the convenience of readers, previously published data on the decline in strike activity in the five common law countries covered by this project from 1960 to $2006 .^{23}$

\footnotetext{
${ }^{20}$ Keith Ewing and John Hendy, Days of Action: The Legality of Protest Strikes Against Government Cuts (Institute for Employment Rights, Liverpool 2011); Seth Kupferberg, 'Political Strikes, Labor Law, and Democratic Rights' (1985) 71 Va L Rev 685.

${ }^{21}$ Fantasia (n 12) 3. This is not to imply that structural processes are disconnected from cultural ones and that struggle emerges either spontaneously or under material conditions that impede social action. Rather, the emphasis is on their dialectical interaction and the possibility of vicious or virtuous circles.

${ }^{22}$ Clark Kerr and others, Industrialism and Industrial Man: The Problems of Labor and Management in Industrial Growth (OUP, New York 1964) 184.

${ }^{23}$ van der Velden (n 12); John Goddard, 'What Happened to Strikes?'(2011) 49 Brit J Ind Relat 282.
} 
Figure 1

Days Lost to Disputes Per Thousand Workers

Australia

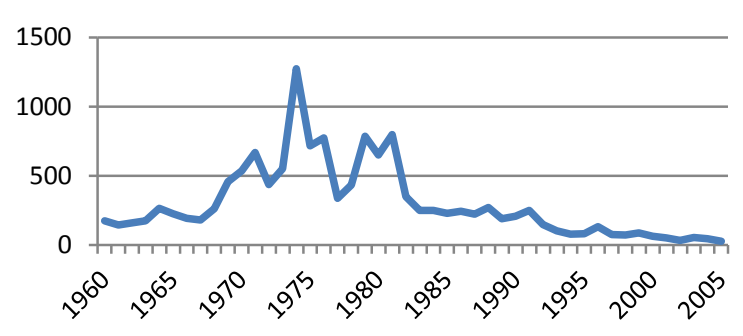

Canada

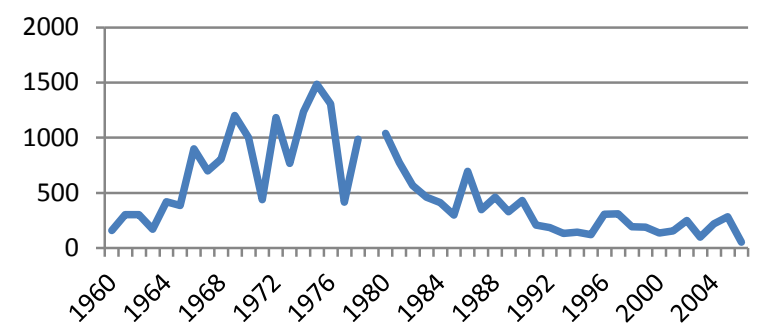

New Zealand

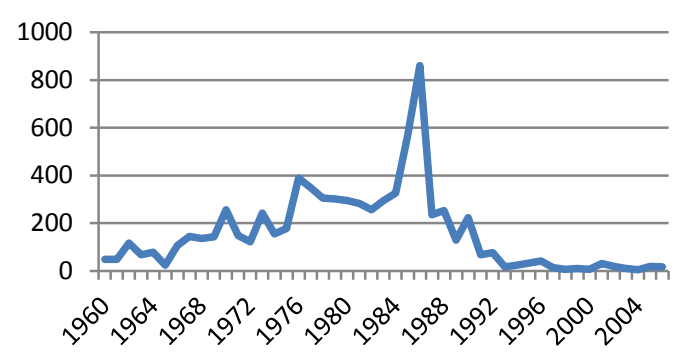

\section{United States}

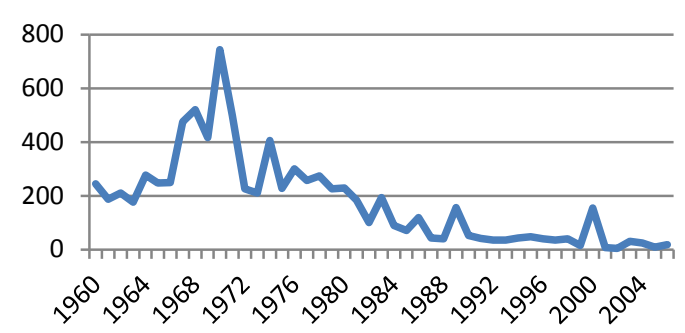

United Kingdom

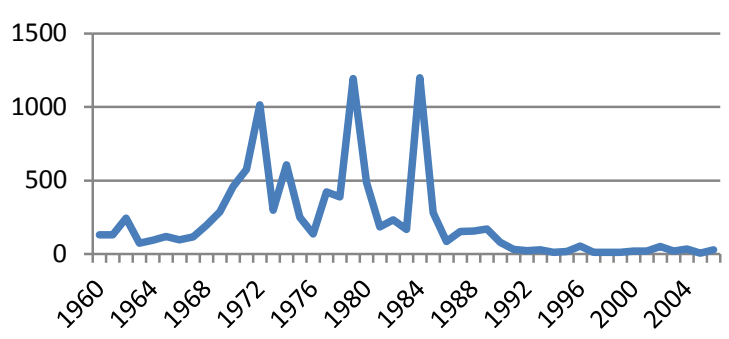

Sources: van der Velden (n 12) 111, 152, 194, 365; Domenic Hale, 'International Comparisons of Labour Disputes in 2006' (2008) 2 ELMR 32. 
The strike data is, well, striking, but to make the evidence of decline even clearer Figure 2 below presents the trend lines for the five countries. Regardless of the starting point, there is a convergence toward quiescence, bordering on disappearance, a trend noted by Shalev in the early 1990s. ${ }^{24}$

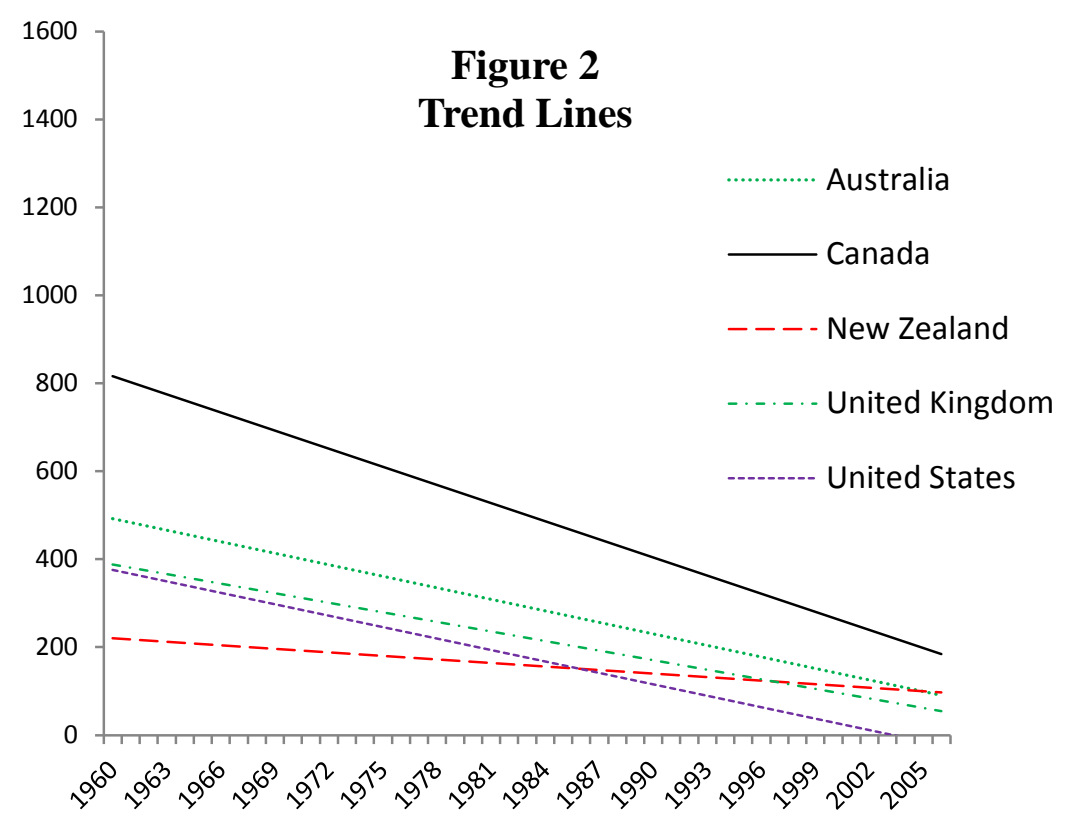

We will turn to discuss the reasons for this development, but first I want to explore whether national statistics hide within them distortions or variations that might be notable. A brief overview of this kind cannot undertake a review of each of the five cases, so I will only consider the Canadian data. In particular, I want to consider whether the declining strike rate is an artifact of the decline in union membership and whether there are different trends for public and private sector strike rates.

Figure 3 presents a comparison of the strike rate calculated per 1000 employees and the strike rate per 1000 union members. If the decline was simply a function of the decline in union density, then one would expect the union member strike rate to remain flat while the employee strike late declined. However, the figure shows that the union member strike rate is declining more rapidly than the employee strike rate, indicating that the decline in union density explains

\footnotetext{
${ }^{24}$ M Shalev, 'The Resurgence of Labour Quiescence’ in Mario Regini (ed), The Future of Labour Movements (Sage, London 1992).
} 
very little of the total decline in strike activity.

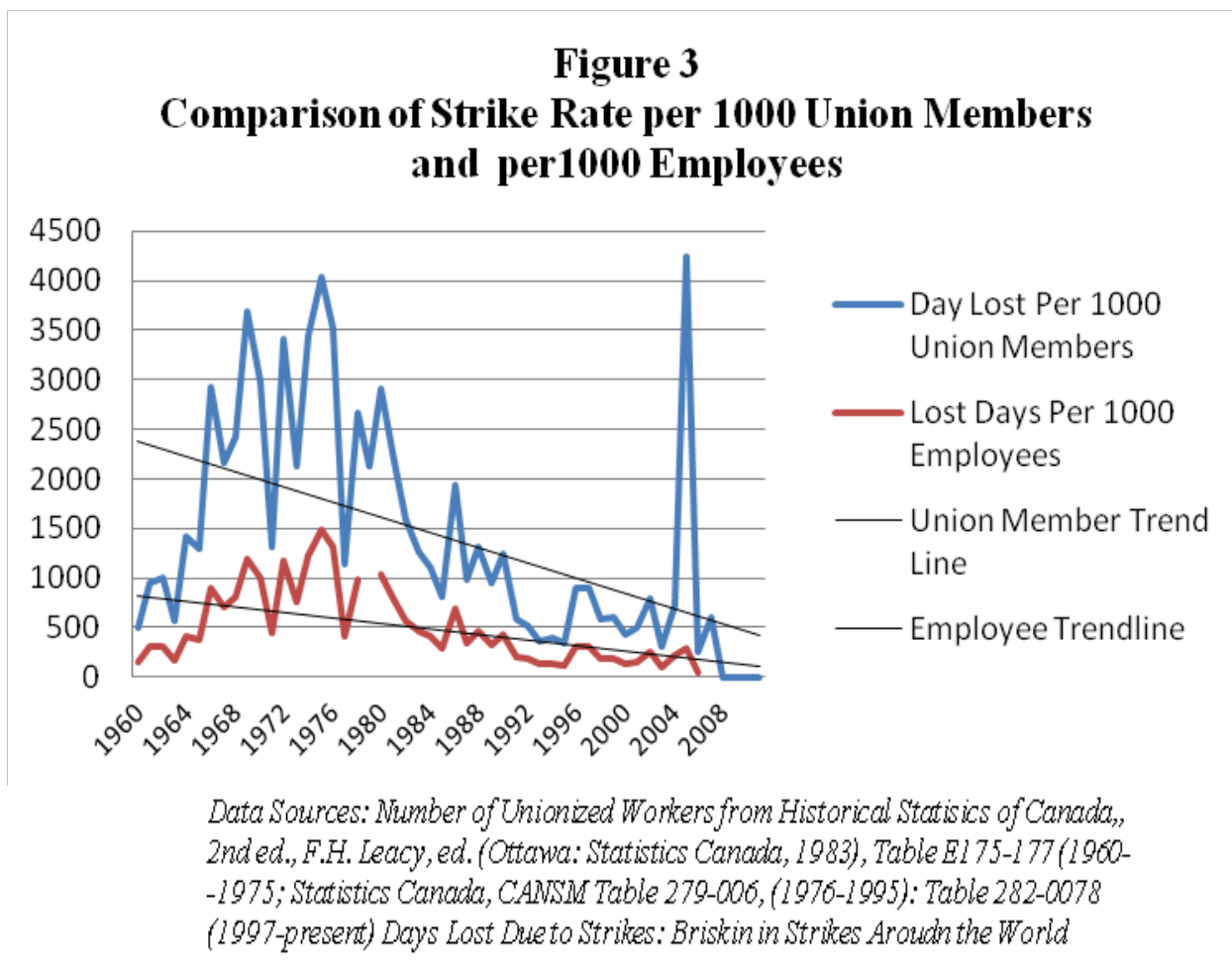

Figure 4 compares changes in strike rates for public and private sector workers. Given the great difference in the trajectory of union densities in these two sectors, with public sector density remaining high, while private sector union density declining, it might have been thought that the public sector strike rate would not decline as rapidly as the private sector strike rate, especially given the findings of previous studies that strike activity varied with union membership. ${ }^{25}$ But this is not the case for Canada over the period covered by this chart (19792007). While for the most part the strike rate of public sector workers has been higher than that of private sector workers, and more uneven because of the size of particular strikes, the strike rate is declining at about the same rate as it is for private sector workers. ${ }^{26}$

Of course, if we did a more refined set of sectoral trend lines, we might discover some differences, but it is unlikely to change the overall picture. In Canada, and probably in the other jurisdictions, union members are striking less frequently now than they have in the past and the rate of public sector strikes, despite higher union densities, is declining about as rapidly as the rate of private sector strike. In short, the data suggest that the decline is real and pervasive.

\footnotetext{
${ }^{25}$ For example, see Shalev (n 25) 118.

${ }^{26}$ But see M Gunderson and F Reid, 'Public Sector Strikes in Canada' in Gene Swimmer and Mark Thompson (eds), Public Sector Collective Bargaining in Canada (IRC Press/Industrial Relations Centre, Queen’s University, Kingston, ON 1995$) 135$. Their calculation is based on strike days as a percentage of days worked and their data run to 1991 .
} 


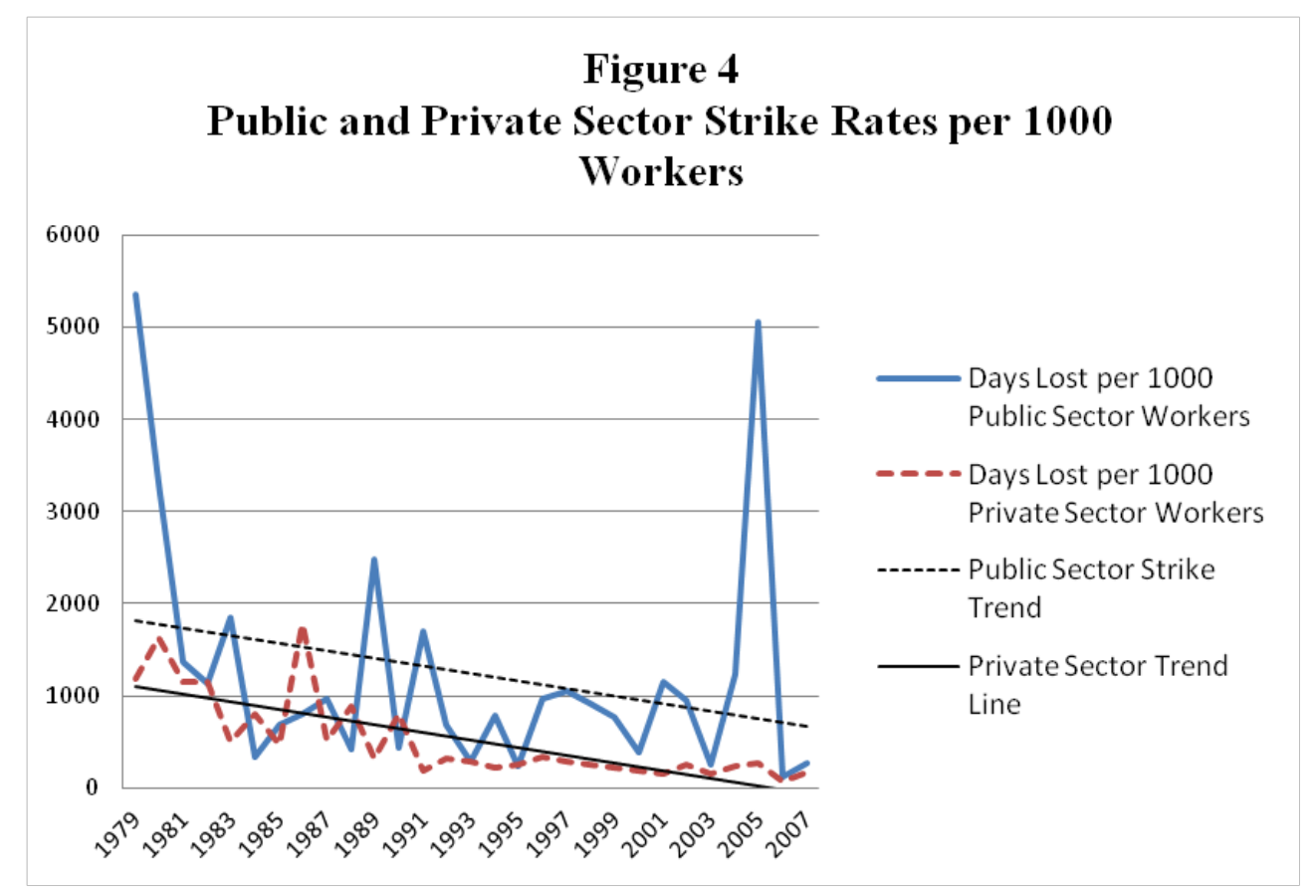

Sources: Days lost due to strikes by sector provided by Robert Hebdon; Public and Private Sector Employment from Historical Labour Force Review, 2010

\section{The Causes of Labour Quiescence: What's Labour Law Got to Do with It?}

The challenge of explaining patterns of strike activity have intrigued numerous scholars. At certain moments, particular theories seemed to have a high order of explanatory power, but subsequent events defeated their predictions, sending scholars scurrying to find new theories that better fit the emerging data. For example, a consensus had emerged that there was an association between strike incidence and the business cycle. ${ }^{27}$ Later, institutional factors came to be more heavily weighed, focusing initially on patterns of working-class mobilization and the extent to which labour was incorporated into political institutions. Yet this explanation too was found wanting a little over a decade after it was published. ${ }^{28}$ Hence caution must be exercised by anyone offering to explain the pattern we have observed above.

The approach proposed here builds on work by Michael Shalev, James Piazza and Robert Brym. It starts from the proposition that there are structural factors that significantly shape the environment for strikes but that institutional factors mediate their effects to a degree. ${ }^{29}$ At a

\footnotetext{
${ }^{27}$ For example, Albert Rees, 'Industrial Conflict and Business Fluctuations’ (1952) 60 J Polit Econ 371.

${ }^{28}$ Walter Korpi and Michael Shalev, 'Strikes, Power and Politics in the Western Nations' (1980) 1 Political Power and Social Theory 301; Shalev (n 25) 110.

${ }^{29}$ Shalev (n 25); James A. Piazza, 'Globalizing Quiescence: Globalization, Union Density and Strikes in 15 Industrialized Countries’ (2005) 26 Econ Ind Democracy 289; R Brym, ‘Affluence, Power, and Strikes in Canada, 1973-2005’ in Edward
} 
structural level, the focus is on the ensemble of economic, political, cultural and ideological arrangements that constitute a social structure of accumulation. ${ }^{30}$ The dominant shift that has occurred since World War II is the shift from the social democratic or Keynesian welfare state to the Neo-Liberalism, which David Harvey has characterized as "a political project to re-establish the conditions for capital accumulation and to restore the power of economic elites." 31 A key strategy of this project was to strip away the buffers that protected workers from being fully exposed to capitalist market ordering. Internationally, this was achieved through globalization, a process that opened up national economies to greater international competition, while domestically the social wage, welfare provision, and other entitlements were scaled back to increase the labour market dependency of the vast majority of the population. At the same time, employers engaged in large-scale workplace restructuring, relocating production in the global south, downsizing local operations, outsourcing into global production networks, substituting contractors for employees, making greater use of temporary employees, etc. ${ }^{32}$ Although there are significant differences in the paths of the jurisdictions under consideration here, they are all operating within this global, neo-liberal structural shift.

In the face of these challenges, the capacities organized labour had developed in the postWorld War II era began to erode and with it their ability to buffer workers against these changes. To a great extent, unions adopted a defensive posture, desperately trying to hold on to past gains often by accepting concessions, such as two-tier wages that protected existing members but put new hires on a lower wage scale with limited prospects for ever catching up. Resort to traditional repertoires of resistance, whether in the form of strikes, as we have seen, or other tactics such as work-to-rule campaigns and plant occupations became less frequent. Perhaps even more fundamentally, neo-liberalism involved a cultural revolution that undermined the "infrastructures of dissent" that had sustained the limited forms of union and working-class solidarity in an earlier era. The ability to imagine it was possible to challenge the neo-liberal order was being lost. $^{33}$

Labour law can be productively viewed as a mediating institution that can either buffer workers against these structural changes or enable them so that they bear more heavily on workers. For example, the law regulating strikes could be changed to prohibit replacement workers in the hope that it will help offset the unfavourable circumstances facing organized labour or strikes could be prohibited or picketing rights restricted to undermine the capacity of unionized workers to resist their greater exposure to market forces. As well, labour law may

Grabb and Neil Guppy (eds), Social Inequality in Canada: Patterns, Problems, Policies (5 ${ }^{\text {th }}$ edn Pearson Prentice Hall, Toronto 2009).

${ }^{30}$ See generally Terrence McDonagh, Michael Reich and David M. Kotz (eds), Contemporary Capitalism and its Crises (Cambridge University Press, Cambridge 2010).

${ }^{31}$ David Harvey, A Brief History of Neoliberalism (OUP, Oxford 2005) 19 (emphasis in the original).

${ }^{32}$ Guy Standing, The Precariat (Bloomsbury, London 2011); Leah Vosko (ed), Precarious Employment (McGill-Queen’s University Press, Montreal 2006).

${ }^{33}$ S Gindin, 'Rethinking Unions, Registering Socialism' in Leo Panitch, Gregory Albo and Vivek Chibber (eds), Socialist Register 2013: The Question of Strategy (Merlin Press, Pontypool, Wales 2013) 26; David McNally, Global Slump: The Economics and Politics of Crisis and Resistance (Fernwood Publishing, Black Point, Nova Scotia 2011); A Sears, 'The End of $20^{\text {th }}$-Century Socialism?' (Summer 2007) 61 New Socialist Magazine 5. 
remain fairly stable, but because the environment in which it operates has changed dramatically, the ability of workers to strike successfully diminishes over time.

There are three dimensions of labour law that are most directly involved in this analysis. First, there is the freedom to strike, which refers to whether and in what circumstances strikes are legally permissible. Second, there is the right to strike, which refers to provisions in the law that protect the exercise of the freedom to strike, such as protection against dismissal or a right to reinstatement. ${ }^{34}$ Finally, there is the law of industrial action that determines what actions striking workers can take to make their strike effective. In the section that follows, I offer a brief and preliminary assessment of the ways in which the law regulating strikes has operated as a mediating variable in the countries covered by this project.

\section{Canada}

It is important to note that most collective bargaining is governed by provincial law and so there are many collective bargaining statutes, although at least with private sector all legislation is based on the Wagner Act model, which imposes significant restrictions on the freedom to strike. Most notably, recognition and mid-term strikes are prohibited and replaced by an administrative recognition procedure and binding grievance arbitration respectively. Generally, strikes are only legal after recognition when no collective agreement is in force. But even then, there are procedural requirements that must be met, including completion of a conciliation process and the taking of a strike vote. Unlawful strikes can result in serious penalties for both the union and participating members. ${ }^{35}$ Apart from restrictions on the freedom to strike, the law also protects striking workers in two ways. First, it provides that strikers retain their status as employees for the purposes of labour statutes and, second, workers have a right to return to their jobs within a certain time (e.g. six months). Only Quebec and British Columbia ban temporary replacement workers. ${ }^{36}$ Finally, the law of picketing has become somewhat less restrictive over the last thirty years or so as some provinces have limited the availability of labour injunctions and the Supreme Court of Canada altered the common law so that secondary action is not per se tortious. ${ }^{37}$

The major change to private sector collective bargaining legislation has been the abolition of card-count certifications in most provinces, resulting in a near exclusive reliance on certification elections. While this change does not directly affect the freedom to strike, studies have demonstrated that it has contributed to a decline in union density, which would undermine

\footnotetext{
${ }^{34}$ Here I am drawing on Hohfeld's distinction between freedoms and rights, which I believe is helpful because it enables us to more precisely describe the way strikes are regulated by law. So when I say there is a freedom to strike I mean that the government and employers have no right to prohibit workers from striking or stop them from doing so. When I refer to a right to strike I mean that governments and employers have a duty not to retaliate or take other adverse action against striking workers or their unions for engaging in strikes. See Wesley Newcomb Hohfeld, 'Some Fundamental Legal Conceptions Applied in Judicial Reasoning'(1913) 23 Yale LJ 28.

${ }^{35}$ For an overview, see Donald D. Carter and others, Labour Law in Canada (5 ${ }^{\text {th }}$ edn Butterworths, Markham 2002); Judy Fudge and Eric Tucker, 'The Freedom to Strike in Canada: A Brief Legal History’ (2010) 15 Can Lab \& Emp LJ 333.

${ }^{36}$ Quebec since 1978 and British Columbia since 1993. Ontario had a partial ban on temporary replacements from 1993 to 1995.

${ }^{37}$ For an overview, see George W. Adams, Canadian Labour Law (2 ${ }^{\text {nd }}$ edn Canada Law Book, Aurora 2003) [11.720]; R.W.D.S.U., Local 558 v. Pepsi-Cola Canada Beverages (West) Ltd. 2002 SCC 8 .
} 
bargaining strength and make unions more reluctant to strike. Dachis and Hebdon found that the introduction of mandatory secret ballots results in a decrease in strike frequency, but that the effect is weakly statistically significant and so at best would explain only a small part of the decline. ${ }^{38}$ More generally, it is fair to conclude that changes to private collective bargaining law have not been a significant cause of the decline in private sector strike activity, but that in the context of less favourable structural conditions private sectors workers are less able to successfully use the limited freedom and right to strike and picket that the law provides.

The story is different for the public sector, where government intervention in strikes has increased over time, even though the baseline was more restrictive than in the private sector. When public sector collective bargaining legislation was first enacted in the 1960s, not only did the law impose the same limits on the freedom to strike that were imposed in the private sector, but there were additional ones as well, including absolute prohibitions and essential service designations where the public interest could be adversely affected. Where strikes were prohibited or severely limited, binding interest arbitration by a neutral third party was the most commonly substituted dispute resolution mechanism. However, as Keynesianism began to be supplanted by neoliberalism, governments found that the already restrictive public sector collective bargaining regime was not restrictive enough and they frequently imposed further limits on the freedom to strike in a number of ways. There has been increasing use of ad hoc measures, like back to work legislation ending strikes or wage restraint legislation that made strikes illegal either by outright prohibitions or by extending the term of existing collective agreements so that a strike would violate the ban on mid-term strikes. As well, governments have also expanded essential service designations, which deprive more workers of the freedom to strike. Leo Panitch and Donald Swartz have aptly characterized the sum total of these changes as “permanent exceptionalism.”39

There is little empirical evidence on the combined impact of these interventions on strike incidence. Dachis and Hebdon find that an essential service designation does not significantly affect the likelihood of a strike and that following back-to-work legislation it is more likely that government will intervene in the next contract. ${ }^{40}$ Perhaps the most that can be said is that changes in public sector labour law make a marginal independent contribution to the decline in public sector strike frequency. More importantly, they are part of a larger government strategy of imposing public sector wage restraint and creating an environment in which public and private sector workers' expectations will be diminished.

\section{United States}

\footnotetext{
${ }^{38}$ Adams (nt 38) 13.

${ }^{39}$ Panitch (nt 17). More generally, see M Thompson and P Jalette, ‘Public Sector Collective Bargaining' in Morley Gunderson and Daphne Taras (eds), Canadian Labour and Employment Relations ( $6^{\text {th }}$ edn Pearson, Addison, Wesley, Toronto 2009); Joseph B. Rose, 'Public Sector Collective Bargaining: From Retrenchment to Consolidation' (2004) 59 Indust Relations 271.

${ }^{40}$ Adams, (nt 38) 12, 17.
} 
The story in the United States is perhaps best understood as one in which the erosion of labour rights in the decades after the 1935 Wagner Act removed important institutional buffers that became increasingly significant in the late 1970s with the turn to neo-liberalism, as the nonunion employers more fiercely resisted the unionization of their employees and unionized employers fought to weaken the collective agreements that bound them. The result was a sharp decline in private sector collective bargaining density and strike incidence.

It is notable that the Wagner Act imposed fewer restrictions on strikes than the Canadian law that was modeled on it. The power of federal courts to issue labour injunctions in nonviolent strikes, including secondary action, was removed in 1932 by the Norris-La Guardia Act. $^{41}$ The Wagner Act itself famously protected the right to engage in concerted activity in section 7 and section 13 specified that nothing in the Act should be "construed so as either to interfere with or impede or diminish in any way the right to strike or to affect the limitations or qualifications on that right." 42 Neither mandatory conciliation nor strike votes were stipulated as preconditions of strike legality.

Despite the Act's broad statutory language, legislation and labour board and judicial decisions began to restrict the freedom to strike in the decades after its enactment. ${ }^{43}$ The 1947 Taft-Hartley Act prohibited jurisdictional strikes, wildcat strikes, strikes by federal government employees and, most importantly, secondary action. It required unions and employers to give 80 days notice before striking or locking out and authorized the President to intervene in strikes that imperiled the national health. This included the power to appoint of a board of inquiry and, more importantly, authorized the Attorney General to seek an injunction while the board sought to resolve the dispute. Finally, the law strengthened the powers of the National Labor Relations Board (NLRB) to enjoin strikes and gave employers the right to sue for damages resulting from secondary action or from strikes in breach of the collective agreement. ${ }^{44}$

The United States Supreme Court (USSC) also played a crucial role in restricting the right and freedom to strike. The Wagner Act neither prohibited mid-term strikes nor required binding interest arbitration to resolve disagreements over the interpretation and application of the collective agreements. While many collective agreements contained no-strike clauses, it was difficult to enforce them until 1957 when the USSC interpreted a provision of the Taft-Hartley Act as authorizing federal courts to enjoin strikes where the agreement contained a no-strike pledge. Three years later, in the so-called Steelworkers' Trilogy, the USSC ruled that even in the absence of a no-strike clause, there was a legal presumption that mid-term strikes were prohibited and disputes were to be resolved by arbitration. The court later held that unions that

\footnotetext{
${ }^{41}$ Michael H. LeRoy and John H. Johnson IV, 'Death by Lethal Injunction: National Emergency Strikes Under the Taft-Hartley Act and the Moribund Right to Strike’ (2001) 43 Ariz L Rev 63, 92.

4229 U.S.C. §§ 151-169.

${ }^{43}$ Karl Klare, 'Judicial Deradicalization of the Wagner Act and the Origins of Modern Legal Consciousness, 1937-1941'(1978) 62 Minn L Rev 265; James Gray Pope, 'How American Workers Lost the Right to Strike, and Other Tales' (2004) 103 Mich L Rev 544; Holly J. McCammon, 'Legal Limits on Labor Militancy: U.S. Labor Law and the Right to Strike since the New Deal' (1990) 37 Soc Prob 206; Burns (nt 3) ch 3.

${ }^{44}$ LeRoy (nt 32).
} 
breached the collective agreement could be sued and that a strike in violation of the express or implied no-strike pledge could be enjoined, notwithstanding the Norris-LaGuardia Act. ${ }^{45}$

Another limitation on the right to strike developed out of the distinction between mandatory and permissive bargaining issues, a distinction not found in statute but created by the NLRB. Its power to make this distinction was upheld by the USSC in 1958. Mandatory issues are ones that the parties must bargain over if one of them wishes and can be bargained to impasse while permissive ones, which relate to matters that are at the core of entrepreneurial control, are not subject to the duty to bargain in good faith and cannot be bargained to impasse. As a result, unions cannot legally strike over crucial issues, such as technological change and changes in the production process, and the tendency over time has been for the scope of permissive bargaining issues to grow. ${ }^{46}$

The most significant judicial decision affecting strikes, however, has been the 1938 judgment in Mackay Radio, in which the USSC held that employers had the right to hire permanent replacement workers. Initially, the use of permanent replacements was infrequent, largely limited to the southern United States where opposition to unionization remained fierce. This began to change in the 1970s as employers more aggressively opposed unions, but it was after President Reagan ordered the hiring of permanent replacement workers in the 1981 strike by the Professional Air Traffic Controllers’ Organization (PATCO) that the use of replacements became more widespread. At the same time, the Supreme Court issued a number of decisions that provided greater protection to permanent replacements. ${ }^{47}$ The combination of low union density, weak bargaining power and a legal framework that provides striking workers with no buffers against hyper-competitive labour markets understandably has made unionized workers reluctant to collectively withdraw their labour.

With private sector unionism weakened, politicians have increasingly focused attention on limiting public sector unions and collective bargaining. The focus here, however, has not been on strikes, since the freedom of public sector workers to strike was already quite limited. Rather, most changes in public sector labour law have aimed to give government greater control over interest arbitration, the commonly provided to resolve disputes when strikes are prohibited, so that they can impose wage restraint.

\footnotetext{
${ }^{45}$ Katherine Stone, ‘The Post-War Paradigm in American Labor Law’ (1981) 90 Yale LJ 1509, 1523.

${ }^{46}$ Thomas T. Crouch, 'The Viability of Distinguishing between Mandatory and Permissive Subjects of Bargaining in a Cooperative Setting: In Search of Industrial Peace’ (1988) 41 Vand L Rev 577.

${ }^{47}$ NLRB v Mackay Radio \& Telegraph Co., 304 US 333 (1938); Michael H. LeRoy, 'Regulating Employer Use of Permanent Striker Replacements: Empirical Analysis of NLRA and RLA Strikes 1935-1991' (1995) 16 Berkeley J Emp \& Lab L 169; John Logan, 'Permanent Replacements and the End of Labor's “Only True Weapon”' (2008) 74 International Labor and WorkingClass History 171; Joseph A. McCartin, Collision Course: Ronald Reagan, the Air Traffic Controllers and the Strike that Changed America (OUP, New York 2011) and J McCartin, 'Approaching Extinction: The Decline of Strikes in the United States, 1960-2005' in van der Velden (n 12) 144 (“most important single event in determining the subsequent fate of strikes in the US”); Matthew Finkin, 'Labor Policy and the Enervation of the Economic Strike' (1990) 3 U Ill L Rev 547.

${ }^{48}$ Joseph E. Slater, 'Attacks on Public-Sector Bargaining as Attacks on Employee Voice: A (Partial) Defense of the Wagner Act Model'(forthcoming 2013) Osgoode Hall LJ; Martin H. Malin, ‘The Legislative Upheaval in Public-Sector Labor Law: A Search for Common Elements’ (2012) 27 ABA Journal of Labor and Employment Law 149.
} 
In sum, the right to strike was incrementally eroded in the decades following the enactment of the Norris-LaGuardia and Wagner Acts. The cumulative potential of these changes to break strikes was not immediately apparent until the 1970s when employer resistance to collective bargaining increased dramatically. The union-avoidance industry, which grew to meet the demand, was able to exploit the law and raise the cost of strikes to unionized workers so steeply that the tactic often appears suicidal.

\section{United Kingdom}

Legal change has also played a significant role in reducing the incidence of strikes in the United Kingdom, but unlike in the United States it did not precede the neo-liberal turn but rather was an expression of it. The starting point of UK strike law is also quite different. For most of the twentieth century, the law was based on a statutory immunity from the common law, which in the nineteenth century had constructed legal doctrines that exposed striking workers and unions to extensive legal liabilities for the harms caused by strikes. This approach is traced back to the 1906 Trade Disputes Act (TDA), which immunized trade unions taking industrial action in contemplation or furtherance of a trade dispute from tort liability. This produced a broad freedom to strike. However, there was no legal right to strike in that striking workers could be dismissed for breaching their contracts of employment and their re-employment depended on the outcome of the strike. Moreover, collective agreements were not legally binding. The result was an industrial relations system in which strikes were quite frequent, many of them being unofficial actions undertaken locally to address workplace grievances. ${ }^{49}$

The 1968-74 strike wave triggered the first significant effort to use law to reduce the incidence of strikes. In 1971, the Conservative government enacted the Industrial Relations Act (IRA), which aimed to force unions into a legalized framework that drew on elements of American labour law: trade union immunities for strike activity were narrowed; state emergency powers to intervene in strikes were expanded and no-strike agreements were encouraged. Trade unions were having none of it and for the most part they boycotted the IRA's institutions. When the Labour Party formed the next government in 1974, it repealed the IRA, restored the TDA and tried to close judicial loopholes in the immunities opened up by a hostile judiciary. But no positive right to strike was enacted, in large measure because the trade union movement preferred the immunity-based approach. In retrospect this may have been a strategic mistake, but it provided the labour movement with the legal freedom it won it the early twentieth century to conduct strikes with limited exposure to legal liabilities.

This came to an end in 1979 when the Thatcher Conservatives came to power after a massive strike wave in 1978-79, triggered by union opposition to the Labour government's wage restraint policy in the so-called Winter of Discontent. ${ }^{50}$ The Conservative government consciously set about to destroy the power of unions and undermine collective bargaining as part of a broader strategy of promoting neo-liberal restructuring of the British economy. Beginning

\footnotetext{
${ }^{49}$ See generally, Douglas Brodie, A History of British Labour Law (Hart Publishing, Oxford 2003); KD Ewing (ed), The Right to Strike: From the Trade Disputes Act 1906 to a Trade Union Freedom Bill 2006 (Institute for Employment Rights, Liverpool 2006).

${ }^{50}$ Chris Howell, Trade Unions and the State (Princeton University Press, Princeton 2005), ch 4.
} 
in 1980, the government passed a series of laws that made industrial action increasingly difficult. Trade union immunity for secondary action was stripped away, as was immunity for disputes that were not narrowly confined to immediate terms and conditions of work. Secondary picketing became unlawful and limits were placed on the number of pickets. Strike ballots were made mandatory and their requirements became stricter and more complex over time. Unions that failed to comply with the letter of the increasingly labrynthine law faced liability for damages resulting from an improperly called strike. Unions were required to prevent unlawful action by their members or face liability and a legal presumption was later enacted that industrial action was endorsed by the union unless it explicitly repudiated it, in which case the employer could selectively discipline the participants. Finally, all this statutory regulation provided courts with ample opportunities to become involved in strikes by issuing interlocutory injunctions. The combination of growing economic insecurity, more adverse labour laws and major strike defeats, including the 1984 miner's strike, contributed to a major drop in strike frequency in the 1980s and 1990s. ${ }^{51}$

The election of a New Labour government in 1997 did not produce a distinctly different approach to strike regulation. Some greater employment protection was offered to employees engaged in union-endorsed strikes, undertaken for statutorily approved goals and complying with the balloting and notice requirements, but the government did little to alter the highly restrictive web of statutory rules that must be complied with for strikes to be protected, although the courts recently indicated they may interpret these statutory requirements less strictly than they have in the past. ${ }^{52}$ Nothing has been done to loosen the tight limits on picketing. Bob Simpson aptly summarized the situation: "Unions have the right to organize industrial action only when they have taken extensive steps to minimise its impact." 53

\section{Australia and New Zealand}

Australia and New Zealand broke with the prevailing common law approach to collective bargaining when it turned to the arbitration model in the late-nineteenth century and consolidated it in the early twentieth. The arbitration model relied on a mixture of negotiation, conciliation and arbitration. In the event a dispute was not resolved through negotiation or conciliation, either party could refer the matter to a tribunal which issued an award that set terms and conditions of employment that were not only binding on the parties, but that either applied across an occupation and industry and covered both unionized and non-union employees (as in New Zealand) or were made to apply by unions getting employers named in awards (as in Australia). One of the keys to the political success of the award system was its role in substantially reducing strikes. Registered unions were given the power to represent both members and non-members within their jurisdiction. Awards were enforced by an industrial relations inspectorate, assisted and, in some cases, largely supplanted by union officials who enjoyed wide powers of entry to

\footnotetext{
${ }^{51}$ Howell (nt 51) ch 5; Lyddon (nt 12) 339; Bob Simpson, 'Strike Ballots and the Law: Round Six' (2005) 34 ILJ 331 ; Gregor Gall and Sonia McKay, 'Research Note: Injunctions as a Legal Weapon in Industrial Disputes’ (1996) 34 Brit J Ind Relat 567.

${ }^{52}$ Ruth Dukes, 'The Right to Strike under UK Law: Something More Than a Slogan? NURMT v SERCO, ASLEF v London \& Birmingham Railway Ltd.’ (2012) 40 ILJ 302.

53 Simpson (nt 52) 337. Generally, see Lorber (nt 15) ch 5 and Shae McCrystal and Tonia Novitz, '”Democratic’ Pre-conditions for Strike Action: A Comparative Study of Australian and UK Labour Legislation' (2012) 28 Int'l J Comp Lab L and Ind Rel 115.
} 
speak to workers and monitor award compliance. Strikes were seen as unnecessary in such a system. Industrial relations statutes sometimes banned industrial action as did some awards, making unions liable for damages. As well, unions faced common law liabilities for unlawful industrial action and secondary action was prohibited by trade practices legislation. In practice, the award system did not prevent strikes, especially in Australia, and the legal sanctions for unlawful strikes were rarely invoked. ${ }^{54}$

The demise of the award system was part of a neo-liberal project aimed at deconstructing institutional arrangements that insulated employment conditions from market forces. However, the move to a de-centralized collective bargaining system that was more responsive to market conditions also required a market-based dispute resolution mechanism, which led to legal recognition of the right to strike. But in this context, the right to strike had to be tailored to insure that it did not empower unions to disrupt the economy in any significant way. Thus, there was a dual movement, legal recognition of strikes one the one hand but only within very narrow and effectively enforced limits on the other, the latter "smothering" the former, ${ }^{55}$ albeit more completely in Australia than New Zealand, particularly after the most recent wave of legislative reforms.

In New Zealand, the concept of a lawful strike was first introduced in 1987 but was substantially revised in the context of the Employment Contracts Act in 1991, which aimed to deunionize workplaces and limit collective bargaining. Strikes were broadly defined to include almost any concerted action that interfered with the performance of work, the effect of which is to bring most forms of collective worker action within the restrictive strike regime. Strikes were unlawful if they occurred while a collective agreement was in force; they could not occur until a period of bargaining had elapsed; and secondary and sympathy strikes were prohibited, as were coordinated strikes for pattern bargaining and political strikes. Unlawful strikes could be enjoined by the courts and participants could be sued for damages and possibly dismissed. The strike regime was liberalized by the Labour government's Employment Relations Act in 2000. Strikes for multi-employer agreements were permitted and, most importantly, significant restrictions on the use of replacement workers were imposed. These legislative changes, however, have had not prevented union density and strike frequency from declining. ${ }^{56}$

The strike regime implemented in Australia is more restrictive than the New Zealand one. A restrictive legal right to strike was first introduced in 1993 and then modified in 1996. It was the 2005 Work Choices Act, however, that dramatically altered the industrial relations regime and greatly increased the restrictions of lawful strike activity. As in New Zealand, industrial action is broadly defined. Before engaging in industrial action, a union must apply for permission to conduct a ballot. A condition of obtaining permission is that the union must demonstrate that it had been and continues to be genuinely trying to reach an agreement with the employer. If

\footnotetext{
${ }^{54}$ Gordon Anderson and Michael Quinlan, 'The Changing Role of the State: Regulating Work in Australia and New Zealand 1788-2007' (2008) 95 Labour History 111; C Briggs, 'Strikes and Lockouts in the Antipodes: Neo-Liberal Convergence in Australia and New Zealand', in van der Velden (nt 12); Anderson (nt 20) 206; Breen Creighton, 'Enforcement in the Federal Industrial Relations System: a Paradox’ (1991) 4 Austl J Lab L 197.

${ }^{55}$ Shae McCrystal, ‘Smothering the Right to Strike: Work Choices and Industrial Action’ (2006) 19 Austl J Lab L 198.

${ }^{56}$ Anderson (nt 20) 210; Barry Foster and others, 'Supportive Legislation, Unsupportive Employers and Collective Bargaining in New Zealand’ (2011) 66 Relations Industrielles 192.
} 
permission is granted, the union must arrange for an independent third party to conduct a secret ballot authorizing the proposed action. If the action is approved, the union must provide three days notice to the employer and the strike must commence within 30 days of the ballot or the ballot must be conducted again. Strikes cannot be conducted for pattern bargaining, and midterm strikes, sympathy strikes, secondary boycotts and political strikes are prohibited. Picketing cannot impede the movement of goods and persons in and out of workplaces and injunctions and damages are available to remedy unlawful action. A cooling-off period can be ordered on the request of one of the parties and a strike can be stopped if it is determined that it is causing significant harm to a third party, the bargaining parties themselves or to essential services (which includes the economy itself). Payment by the employer for periods of industrial action is prohibited, even as part of a settlement. In 2009 a Labour government enacted the Fair Work Act, which provides more support for collective bargaining but does not substantially change the strike regime. $^{57}$

\section{Conclusion}

Our brief survey of legal regimes reveals that different jurisdictions have taken different approaches to the legal regulation of strikes. In Canada and the United States, the law regulating strikes has changed very little, perhaps because under the existing collective bargaining regimes unions were faring so poorly there was little apparent need to create even more restrictive ones. A partial exception to this pattern is in the public sector, where trade union densities have remained much stronger. In Canada exceptional interventions to prohibit or end strikes have occurred more frequently, while in the United States the focus has been on undermining strike alternatives, such as interest arbitration. By contrast, in the UK, New Zealand and Australia, legislation was enacted to de-collectivize industrial relations and impose highly restrictive strike regimes. Thus it might be fair to say that law has played a more direct and significant role in these countries, but it is doubtful that changes in the law are the primary reason for the decline in strikes. Rather, it is more accurate to say that in jurisdictions where the law was not an effective buffer against market forces (Canada and the US), there was little need to change the law, while in jurisdictions where strong unions operated with legal immunities (UK) or where industrial relations regimes insulated workers against market forces (AU \& NZ), legal changes were made to undercut trade union power and impose more restrictive strike regimes.

\section{The Future of Strikes}

Given the demise of the strike, what is to be done? One answer might be that nothing is to be done. Strikes have disappeared because the sources of conflict have diminished and the sources of peace have become more significant. The unitarist perspective has triumphed. ${ }^{58}$ This seems unlikely in a world in which workers have seen their share of socially produced wealth decline and their standard of living is under attack. A more realistic starting point is that workers are frequently dissatisfied with their terms and conditions of work, but that strike activity is

\footnotetext{
${ }^{57}$ Shae McCrystal, 'The Fair Work Act 2009 (Cth) and the Right to Strike’ (2010) 23 Austl J Lab L 3 and Shae McCrystal, The Right to Strike in Australia (Federation Press, Sydney 2010). Also, see McCrystal (nt 54).

58 The framework but not the conclusion is from Richard Hyman, Strikes (Fontana, London 1972). For an insightful discussion of the issues touched on here, see J Goddard, 'What Has Happened to Strikes' in Hyman (above in this note) 282.
} 
depressed because workers are also disorganized and disempowered. That dissatisfaction may remain latent or manifest itself in informal or non-union forms of collective action that do not develop into strikes or individualized forms of resistance or dysfunction. Where workers do act in these ways, individually or collectively, there is little evidence it leads to a successful resolution of the problem(s) they encountered, let alone fulfills the democratic or classconsciousness development functions of strikes. ${ }^{59}$ If that is the case, there is indeed an urgent need to consider how collective worker voice might 'strike' again.

One focus might be on reforming laws that make strikes particularly difficult to win and risky to conduct. In the United States, for example, there is no doubt that the right of employers to hire permanent replacement workers, in conjunction with greater opportunities and motivation to do so, has undermined the ability of unionized workers to strike successfully. ${ }^{60}$ In some countries, appeals to constitutional protection of freedom of association, whether in national or transnational law, may provide some leverage in limiting state restrictions on the freedom to strike, but the road ahead is uncertain. ${ }^{61}$ In any event, as we have seen, unfavourable laws are not the primary cause of the demise of strikes, and so it can be anticipated that the impact of legislative reform or sympathetic constitutional interpretation would be modest.

Another possible area is the development of new strategies and tactics. Traditional strikes were successful in a world in which the collective withdrawal of labour inflicted or threatened to inflict significant economic costs on employers so that they preferred to settle on terms more favourable to the union. Moreover, through the act of striking, workers learned the practice of solidarity and were themselves transformed and made more class conscious. If traditional strikes no longer provide workers with leverage or collective voice, then new forms of collective action should be developed. Workplace occupations, bossnappings and corporate campaigns have been identified as alternatives to traditional strikes, but as Gregor Gall concludes, "So thus far, even sympathetic and engaged observers would have to conclude that the ability of organised labour to offer widespread, let alone effective resistance has been shown to be badly wanting.", 62

Part of the problem is that unions have been shaped by the legal frameworks in which they operate. As a result, they often became narrowly focused on pursuing the interests of their members through collective bargaining and developed a repertoire of actions, permitted within the legal framework, to advance those interests. Reforming the legal framework and expanding the repertoire while keeping the same narrow focus is unlikely to lead to much change. Perhaps

\footnotetext{
${ }^{59}$ For a recent review, see Diane van den Broek and Tony Dundon, '(Still) Up to No Good: Reconfiguring Worker Resistance and Misbehaviour in an Increasingly Unorganized World' (2012) 67 Relations Industrielles 97. Also, see Anna Pollert and Andy Charlwood, 'The Vulnerable Worker in Britain and Problems at Work’ (2009) 23 Work Employ Soc 343.

${ }^{60}$ Logan (nt 48).

${ }^{61}$ In Canada, for example, the Saskatchewan Court of Appeal recently overturned a lower court judgment that held the Canadian Charter of Rights and Freedoms protected the freedom to strike on the basis that this judgment was inconsistent with previous Supreme Court of Canada decisions. Saskatchewan v Saskatchewan Federation of Labour 2013 SKCA 43 (overruling 2012 SKQB 43). Undoubtedly, the Supreme Court of Canada will be asked to reverse these older judgments in the near future.

${ }^{62}$ Gregor Gall, ‘Worker Resistance and Response to the Crisis of Neo-Liberal Capitalism’ (2011) 33 Employee Relations 588. Also see Lucio Baccaro, 'Does the Global Financial Crisis Mark a Turning Point for Labour?' (2010) 8 Socio-Economic Review 341, 347 (If strategy was at stake, one would expect to find that at least in some cases...unions were getting it right.)
} 
what is needed is a more fundamental shift that would see unions trying to rebuild as workingclass movements more broadly focused on organizing and advancing the interests of working people outside of the framework of contract unionism. ${ }^{63}$ Strikes may be an important vehicle for the achievement of these goals. Notable in this regard have been one-day strikes by Walmart and fast-food workers demanding higher wages, even though there is no prospect that they will be organized into dues paying bargaining units. ${ }^{64}$

Finally, there is the turn to international solidarity. Strikes were effective when the geographic scope of worker organization matched that of their employers. If locally organized unions could take on local, immobile employers and national industrial unions could take on national manufacturers, then international worker institutions are necessary to take on globally organized employers. No doubt this is correct and while global labour solidarity is being constructed, its slow pace and the difficulties facing this project leave little room for optimism that a globally organized working class is going to become the vehicle for collective worker voice and resistance in the near or medium-term future. ${ }^{65}$

Perhaps the answer to the question of what is to be done is that there is no good answer at this juncture. Reforming the law of strikes, launching constitutional challenges to restrictive strike laws, developing innovative strategies and tactics and building international solidarity are all important projects that may help open up more space for collective worker voice now and in the future, but the inhospitable socio-economic climate severely limits what can be achieved.

\footnotetext{
${ }^{63}$ David Camfield, Canadian Labour in Crisis (Fernwood Press, Halifax 2011).

${ }^{64}$ Karen McVeigh, 'Walmart workers protest over minimum wage in 15 US cities’ Guardian (London 5 September 2013) http://www.labourblawg.ca/strikeslockouts/fast-food-strikes-spread-to-new-us-cities-and-in-canada-baristas-seek-to-unionize/ accessed 10 September 2013; Atossa Araxia Abraham, 'Fast food workers begin strikes across U.S. over wages' Globe and Mail (Toronto 29 August 2013) http://www.theglobeandmail.com/report-on-business/international-business/us-business/us-fast-foodworkers-plan-nationwide-strikes-over-wages/article14018751/ accessed 10 September 2013.

${ }^{65}$ David Christopher Lier, 'Places of Work, Scales of Organising: A Review of Labour Geography’ (2007) 1 Geography Compass 814. Law plays a role in this by, for example, forbidding secondary action that would enable workers in one country to disrupt the economic activity of a struck employer in another. See Bob Hepple, Labour Laws and Global Trade (Hart Publishing, Oxford 2005). For a prescient analysis, see KW Wedderburn, 'Multi-national Enterprise and National Labour Law' (1972) 1 ILJ 12.
} 